\title{
Review of Road Drainage System-A Case Study of Nsukka Town in Enugu State, Nigeria
}

\author{
${ }^{1}$ C.N. Mama, ${ }^{1}$ A.C. Nweze, ${ }^{2}$ P.I. Obe, ${ }^{1}$ C.C. Nnaji, ${ }^{1}$ I.A. Yakubu and ${ }^{3}$ F.O. Okechukwu \\ ${ }^{1}$ Department of Civil Engineering, University of Nigeria, Nsukka, Nigeria \\ ${ }^{2}$ Department of Industrial Technical Education, University of Nigeria, Nsukka, Nigeria \\ ${ }^{3}$ Department of Home Science and Management, University of Nigeria, Nsukka, Nigeria \\ cordelia.mama@unn.edu.ng,+2348063711674
}

\begin{abstract}
Review in terms of the research undertaken is a formal assessment of the road drainage system in Nsukka town (urban). The eight major roads that convey most traffic were used as case study with the intention of changing or improving them to achieve sustainability. The aim of this review is to evaluate the existing condition of roads and drainage structures, explore the impacts of waste on drainage systems in Nsukka town (urban) and to identify the reasons behind drainage problems in roads focusing on current situation of Nsukka town. Some areas of Nsukka town already have great amount of erosion problem like in Onuiyi-Road and University Road which requires serious attention and this might have occurred due to lack of continuous channelization of drainage systems and on people's opinion on sustainability of these drainage systems. Hence, a conclusion was reached from the product of the research work. Maintenance of many of the existing drainage facilities was found to be poor which has posed a threat to lives and property. Recommendations on both improvements of waste management practices and maintenance or reconstruction of those drainage systems with severe damages, among others were made.
\end{abstract}

\section{Key words: Review, road drainage system, Nsukka town, maintenance, waste management, sustainability}

\section{INTRODUCTION}

Poor drainage is a traffic safety risk. Water may accumulate on the road like ponds. The accumulated water creates a risk of aquaplaning during rain. A wet surface reduces friction which leads to longer braking distances. Surface water can freeze during the night at those times of the year with frost nights and thaw again when temperatures rise above freezing during the day. Where this happens roads may become very slippery and the change in friction may come as a surprise to those who are driving (Leviakangas, 2015).

Uncontrolled water flows on the road area can cause erosion. Culverts are also risk places for erosion. Small diameter and clogged culverts can cause water to flow towards the road and produce erosion. Water exiting from culverts can similarly cause erosion when it discharges directly on to erosive soil. The sensitive soil types for erosion are silt, silty moraine and sand. Vegetation can reduce erosion (Leviakengas, 2015).

Highway drainage is the process of removing and controlling excess surface and sub-surface water within the road way. This includes interception and diversion of water from the road surface and subgrade. The installation of suitable surface and sub-surface drainage system is an essential part of highway design and construction. Highway drainage is used to clear surface water from the highway. Good highway drainage is important for road safety. Roads need to be well drained to stop flooding, even surface water can cause problems with ice in the Winter. Water left standing on roads can also cause maintenance problems as it can soften the ground under a road making the road surface break up and as well lead to an accident from the road users (Amit, 2016).

Mukherjee (2014) studied highway surface drainage system and problems of water logging and concluded that adverse roadway elements contributing to highway accidents were substandard roadway alignment or geometry, lack of shoulders and shoulder defects, absent or inappropriate pedestrian facilities, narrow and defective lanes and bridges/bridge approaches, roadside hazards, undefined pavement centre and edge lines, poor sight distances and visibility, unmarked and inappropriate design of intersections, serious allocation deficiencies along the route, haphazard bus shelters/stops and others are causes of water logging problem in highway. This research traced that proper drainage is a very important consideration in design of a highway. Inadequate

Corresponding Author: C.N. Mama, Department of Civil Engineering, University of Nigeria, Nsukka, Nigeria cordelia.mama@unn.edu.ng,+2348063711674 
drainage facilities can lead to premature deterioration of the highway and the development of adverse safety conditions such as hydroplaning. It is common, therefore, for a sizable portion of highway construction budgets to be devoted to drainage facilities.

Mwangi (2013) studied highway drainage system and stated that highway is importance for removing water from the road surface, preventing ingress of water into the pavement, passing water across the road, either under or over and preventing scour and/or washout of the pavement, shoulder, batter slopes, water courses and drainage structures. He identified types of drainage on the highway to include kerb and gullies, surface water channel, combined filter drain (French drain), over-the edge drainage, drainage channel locks, combined kerb and drainage units, linear drainage channels, fin and narrow filter drain (sub-surface drainage) and edge drainage for porous asphalt.

According to Civil Engineering Dictionary, highway drainage includes collecting, transporting and disposing of surface/subsurface water originating on or near the highway right of way or flowing in streams crossing bordering that right of way. This is important because water damage highway structure in many ways. The water which are dangerous for highways are: Rainwater: cause erosion on surface or may seep downward and damage pavement (surface drains), groundwater: may rise by capillary action and damage pavement (sub-surface damage) and water body: may cross a road (river/stream) and may damage road (cross drainage walls).

In a research on drainage on roads by Singh et al. a well-designed and well maintained road drainage is important in order to: minimize the environmental impact of road runoff on the receiving water environment, ensure the speedy removal of surface water to enhance safety and minimize distuption to road users and to maximize the longevity of the road surface and associated infrastructures. Water in the pavement system can lead to moisture damage, modulus reduction and loss of strength. In order to prevent such damages to the pavement, it is essential to provide proper drainage to the roads. They maintained that the presence of water in a highway layer reduces the bearing capacity of the road, and in doing, so, it also reduces the structure's lifetime. Highway drainage is used to clear surface water from the highway. Roads need to be well drained to stop flooding, even surface water can cause problems with ice in the winter. Water left standing on roads can also cause maintenance problems as it can soften the ground under a road making the road surface break up.

Ger et al., designed the guidelines for road drainage which stressed that drainage is a basic consideration in the establishment of road geometry and in general this means that the drainage should meet the following: cross falls should be a minimum of $2.5 \%$ on carriageways with increased cross falls of up to $5.0 \%$ on hard shoulders draining to filter drains, longitudinal gradients should not be $<0.5 \%$ on kerbed roads, flat areas should be avoided and consideration of surface water drainage is particularly important at rollovers, roundabouts and junctions, outfall levels must be achievable, the spacing of road gullies should be sufficient to remove surface water whilst achieving an acceptable width of channel flow. One gully for every $200 \mathrm{~m}^{2}$ of paved surface is generally found to be satisfactory.

According to Michael et al. (2016), highway drainage should fulfill the following objectives: prevent flooding, ponding and seepage and keep the carriageway, cycle way and foot way as free of standing water as possible, ensure surface water falling on the highway enters the drainage system or natural watercourse as speedily as possible, keep the underlying road structure as dry as possible, prevent injury or damage caused by hazardous surface water, prevent highway surface water flooding adjacent properties and prevent blockages in associated highway drainage systems with consequential flooding.

The council maintained that highway drainage requires routine maintenance to ensure its continued efficiency. From time to time, additional maintenance is essential to ensure the system continues to function properly. Gullies and their immediate pipe connection are emptied and cleaned as part of an annual proactive maintenance programmed. Drainage is cleaned as followed: rural areas-once per year, urban areas-once per year and high-speed dual carriageways twice per year. However, where persistent problems are identified with gully cleansing, for example, being blocked by silt and detritus on a regular basis, the gullies are specifically identified and programmed for a greater cleaning frequency.

As a citadel of learning, Nsukka town is supposed to have good roads, walk ways, etc., linking parts of the metropolis together and since, a good drainage system contributes immensely to the sustainability of the roads, it's worth studying.

This study is of high importance because on the overall, it tries to make sure the government and public have good value for the money spent in the drainage construction and maintenances. The knowledge gotten from here would help us properly maintain our drains which will in turn give us good roads and help to sustain the roads especially from floods and erosion in the town. Water is very essential for all life on earth, it can also cause disasters through erosion and flooding. In fact, the 
surface runoff water is greatly increased in urban areas as a result of the development of infrastructures". So, it is of high importance to really make sure our drains are healthy and sustained.

\section{MATERIALS AND METHODS}

Nsukka town which is in Enugu State, Nigeria (Fig. 1 and 2) and absolutely located at lat. $6.8429^{\circ} \mathrm{N}$ and long. $7.3733^{\circ} \mathrm{E}$ have a total area of $45.38 \mathrm{~km}^{2}$, elevation of $1,800 \mathrm{ft}(550 \mathrm{~m})$ and a population of 309,633 people, according to 2006 census count.

The review was carried out by first of all distributing questionnaires to road users and professionals in the noble field of civil engineering as eight major roads were taken as case study in Nsukka town (urban). Afterwards, a field study was carried out on the roads and their drainages (Mama et al., 2018). Table 1 shows the eight major roads with along with their drainages.

For each of the roads we surveyed on the drainage systems from end to end. This field work consist of waste management and drainage survey in order to correlate the condition of the drainage systems in Nsukka town with the psychology of road users on

\begin{tabular}{ll}
\multicolumn{2}{l}{ Table 1: Road drainage systems used as case study } \\
\hline Drainages & Roads \\
\hline A & Enugu-Road \\
B & Orba-Road \\
C & Odenigwe-Road \\
D & Odenigbo-Road \\
E & Aku-Road \\
F & University-Road \\
G & Onuiyi-Road \\
H & University Market-Road
\end{tabular}

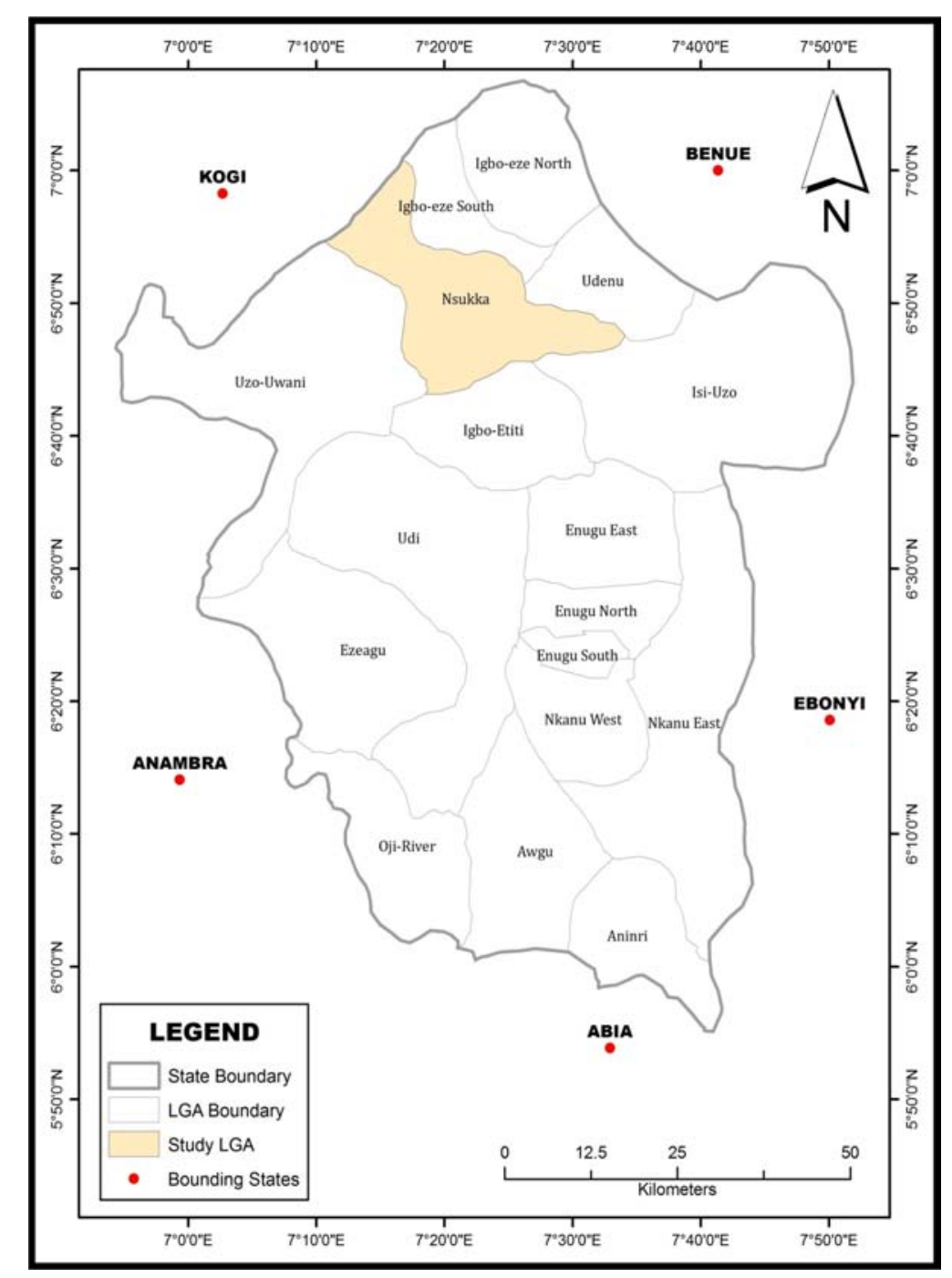

Fig. 1: Map of Enugu State showing Nsukka town 




Fig. 2: Map of Nsukka

their knowledge concerning the sustainability of Nsukka drainage system. The drainage survey includes:

\section{Measurement of their}

- Depths/side lengths

- Width

- Thickness

\section{Broadcasting of the}

- Well-constructed drainage system

- Poorly-constructed drainage system

- Failed drainage systems due to poor maintenance

- $\quad$ Piping system cross-cutting drainage systems

\section{Consideration of the}

- Properties of the channel systems

- The type of drainage system

- The type of culverts, the number of culverts

- The material type

- Possible load bearing effect on the drainage and

- Sections needed to prevent latitudinal siltation

\section{RESULTS AND DISCUSSION}

The results of the review are shown pictorially from Fig. 3-25 b. Figure 3 shows depth variation in University-Road. Figure 4 shows width variations in Onuiyi-Road. Figure 5 shows thickness variation in Aku-Road. Figure 6 shows well-constructed drainage

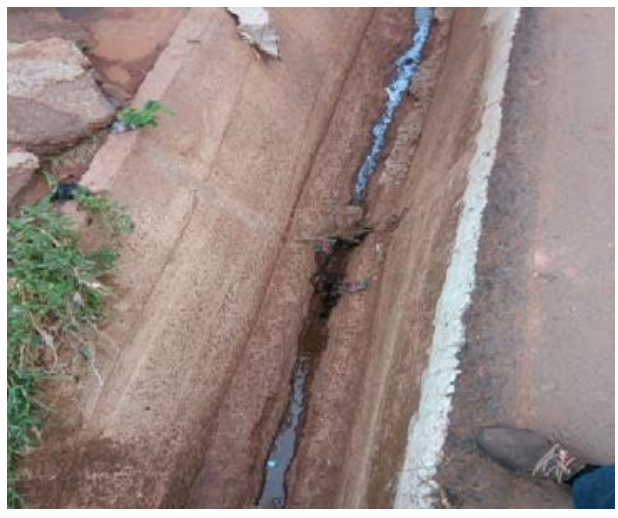

Fig. 3: Depth variation in University-Road

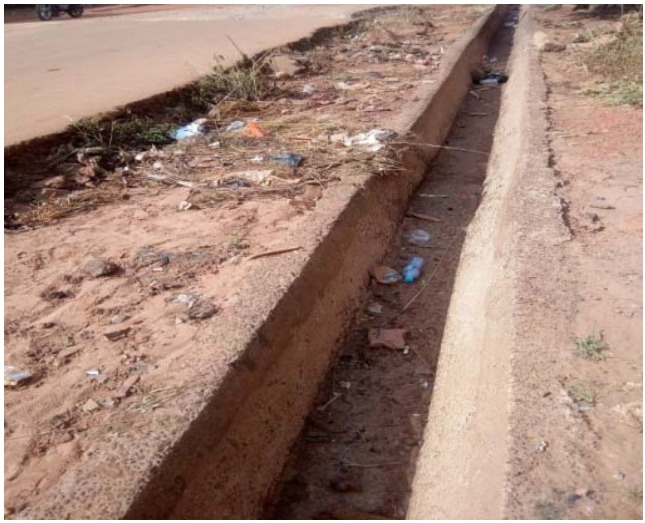

Fig. 4: Width variations in Onuiyi-Road

system in Enugu Road. Figure 7 shows section of poorly constructed drainage system in Aku-Road. Figure 8 shows section of poorly constructed drainage system in 


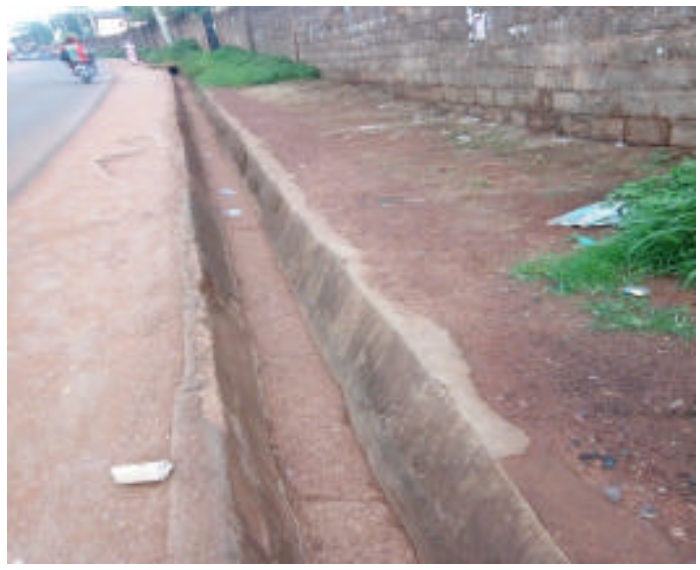

Fig. 5: Thickness variation in Aku-Road

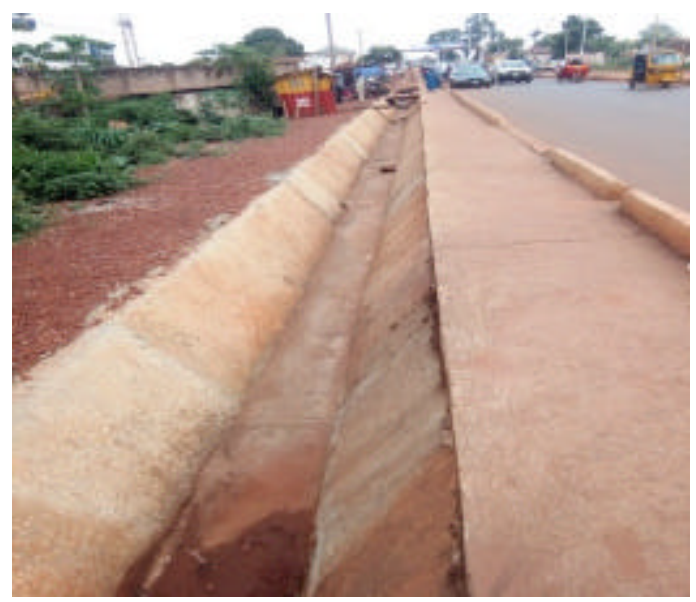

Fig. 6: Well-constructed drainage system in Enugu Road



Fig. 7: Section of poorly constructed drainage system in Aku-Road

Odenigwe-Road. Figure 9a shows sections of failed drainage system in University Market-Road. Figure 9b shows sections of failed drainages system in University Market-Road. Figure 10 shows underlying pipe cutting

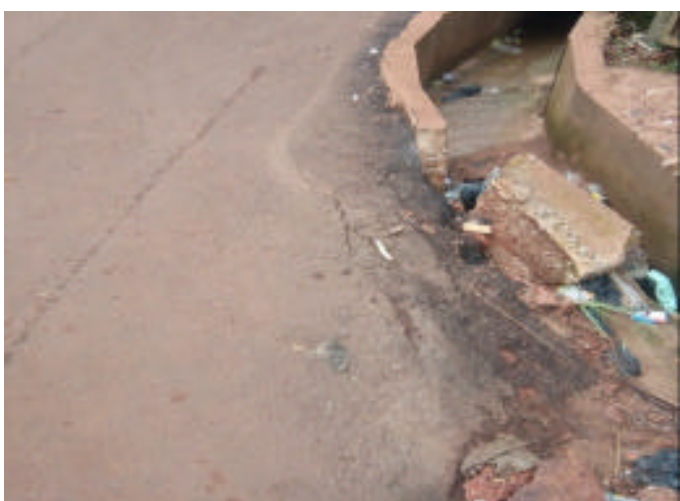

Fig. 8: Section of poorly constructed drainage system in Odenigwe-Road

(a)



(b)

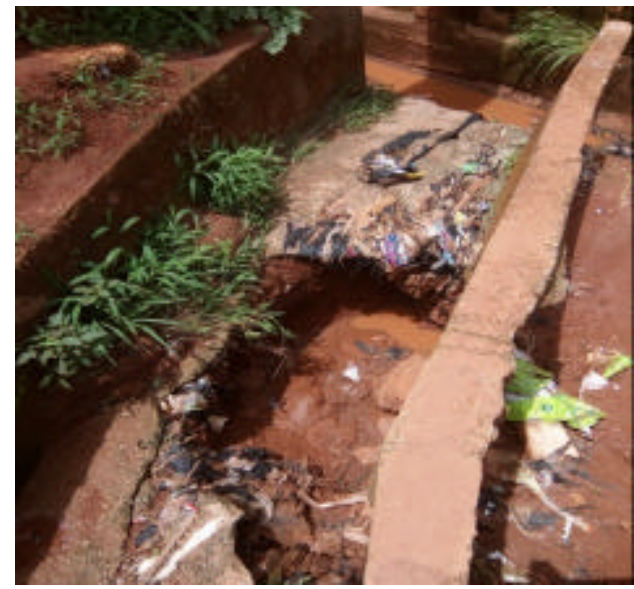

Fig. 9: Sections of failed drainage system in University Market-Road

across the drainage system in Odenigwe-Road and University-Road. Figure 11 shows underlying pipe cutting across the drainage system in University-Road. Figure 12 shows drainage section where latitudinal siltation should 


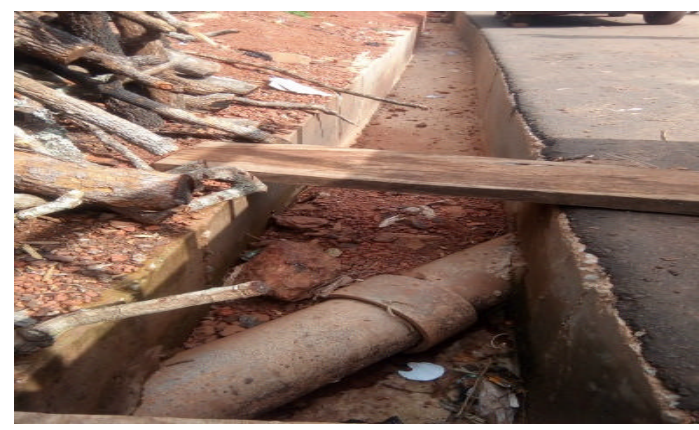

Fig. 10: Underlying pipe cutting across the drainage system in Odenigwe-Road and University-Road

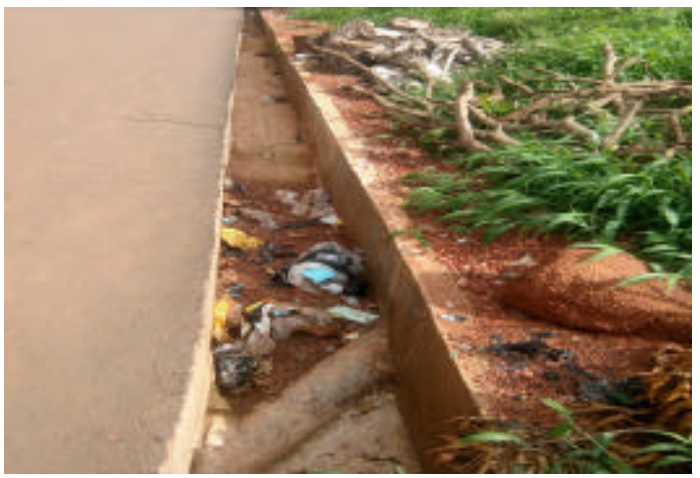

Fig. 11: Underlying pipe cutting across the drainage system in University-Road

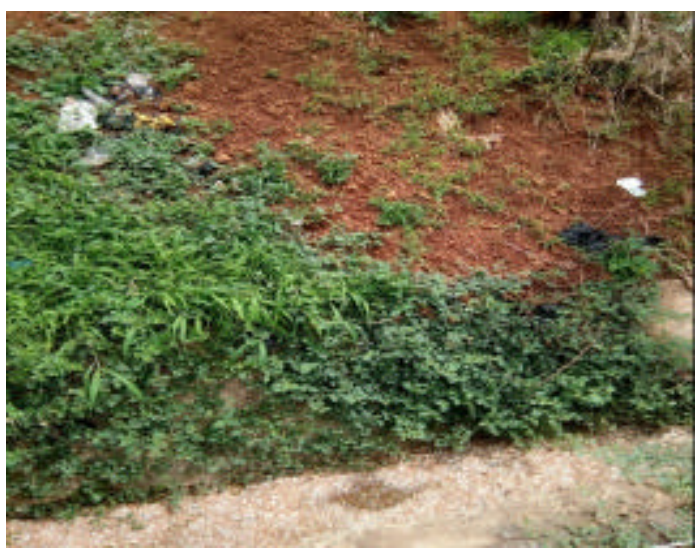

Fig. 12: Drainage section where latitudinal siltation should be prevented in University Market-Road

be prevented in University Market-Road. Figure 13 shows drainage section where latitudinal siltation should be prevented in Odenigbo Road. Figure 14 shows drainage section where latitudinal siltation should be prevented in Enugu-Road. Figure 15 shows drainage section where latitudinal siltation should be prevented in Orba-Road.

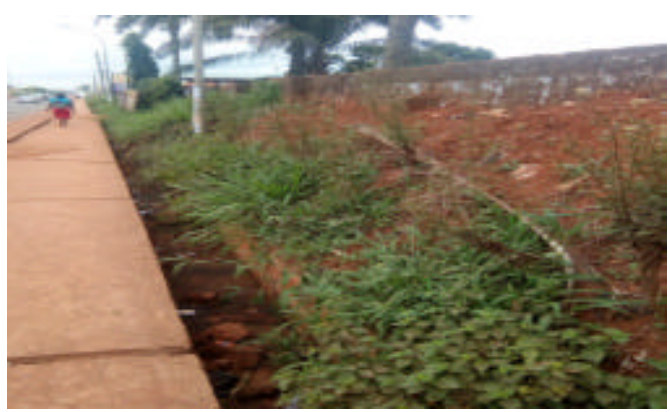

Fig. 13: Drainage section where latitudinal siltation should be prevented in Odenigbo Road

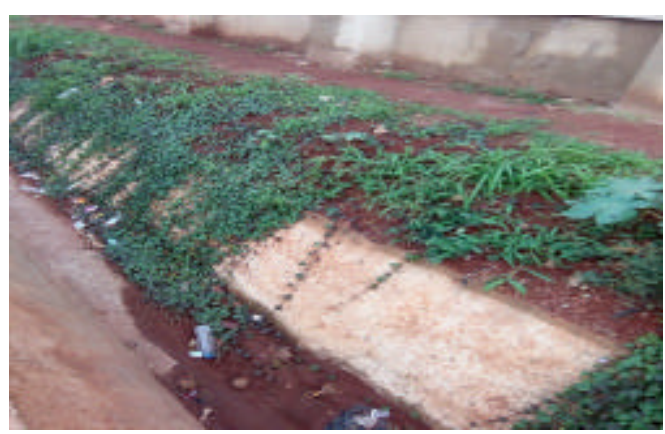

Fig. 14: Drainage section where latitudinal siltation should be prevented in Enugu-Road

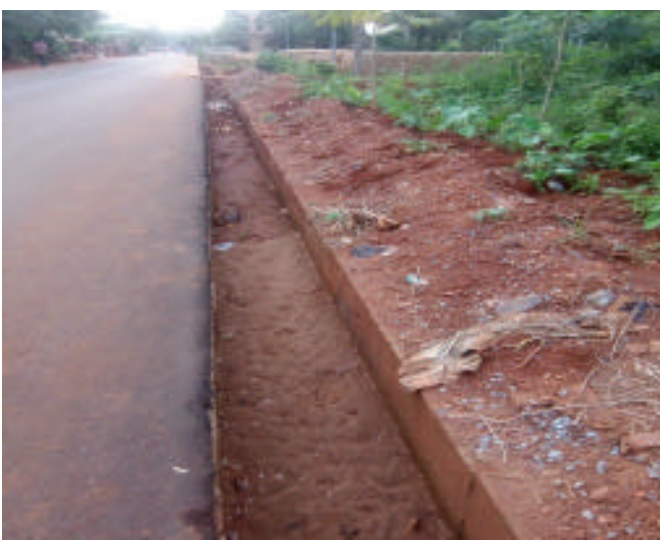

Fig. 15: Drainage section where latitudinal siltation should be prevented in Orba-Road

Figure 16 shows farm land along Odenigwe Road that dissipates fine particles into the drainage system during rain. Figure 17 a shows Roads with good waste management, good drainage condition and without temporary waste site in Enugu Road. Figure 17b shows Roads with good waste management, good drainage 


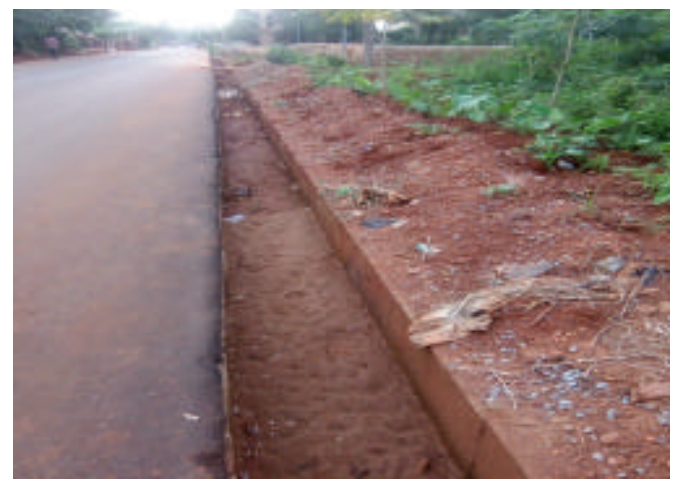

Fig. 16: Farm land along Odenigwe Road that dissipates fine particles into the drainage system during rain

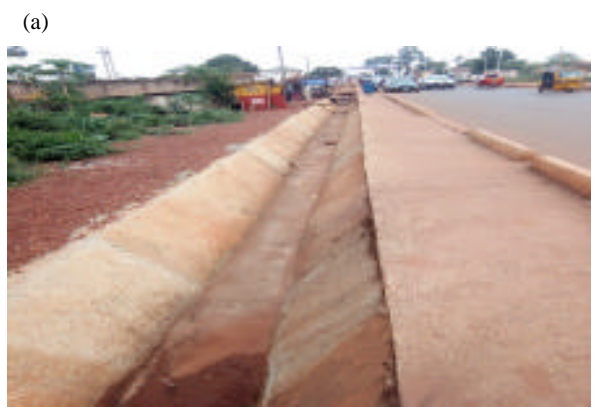

(b)

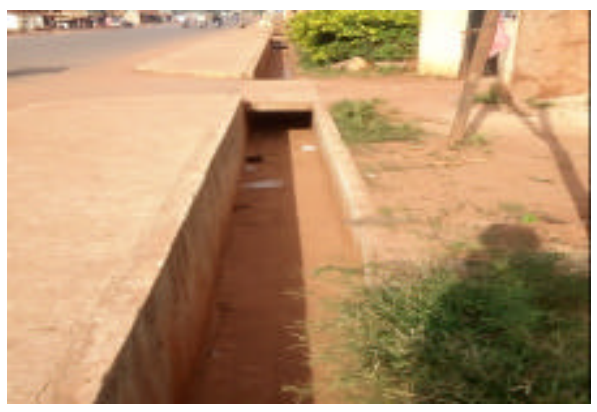

Fig. 17: a) Roads with good waste management, good drainage condition and without temporary waste site in Enugu Road and b) Roads with good waste management, good drainage condition and without temporary waste site in Orba Road

condition and without temporary waste site in Orba Road. Figure 18 shows Road with no temporary waste site, poor waste management and good drainage condition, e.g., Odenigwe-Road. Figure 19 shows Road with temporary waste site, good waste managements and poor drainage condition, e.g., Aku-Road. Figure 20 shows Road with no temporary waste site, poor waste managements and poor drainage, e.g., University-Road. Figure 21a shows Roads with temporary waste site, very good waste managements and very poor drainage condition, e.g.,



Fig. 18: Road with no temporary waste site, poor waste management and good drainage condition, e.g., Odenigwe-Road

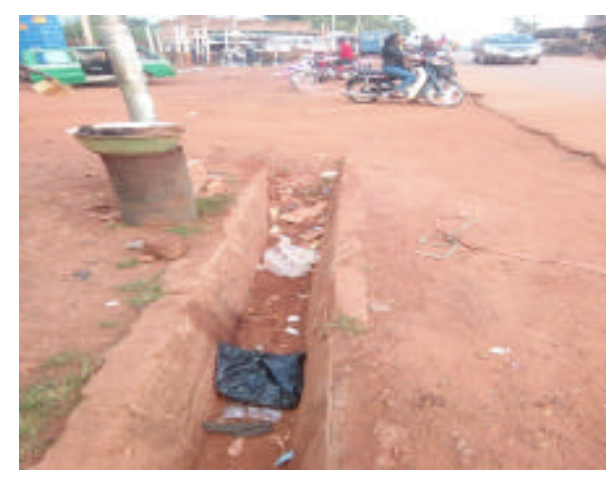

Fig. 19: Road with temporary waste site, good waste managements and poor drainage condition, e.g., Aku-Road

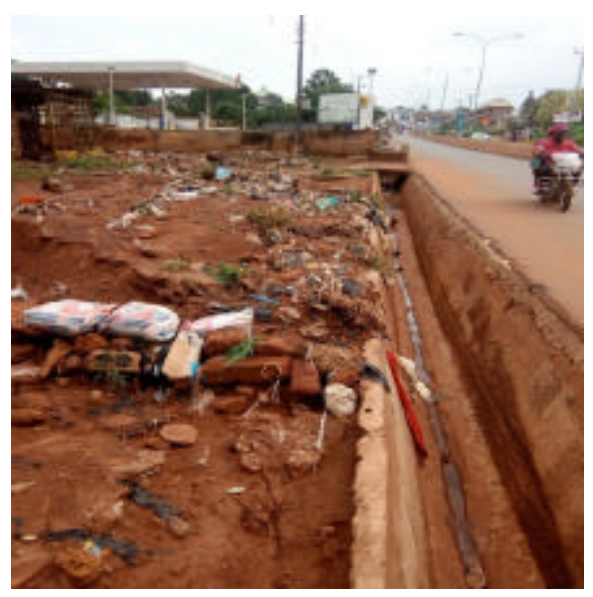

Fig. 20: Road with no temporary waste site, poor waste managements and poor drainage, e.g., University-Road

Onuiyi- Road. Figure $21 \mathrm{~b}$ shows Roads with temporary waste site, very good waste managements and very poor drainage condition, e.g., Onuiyi-Road. Figure 22a shows Roads with temporary waste site, very poor waste 


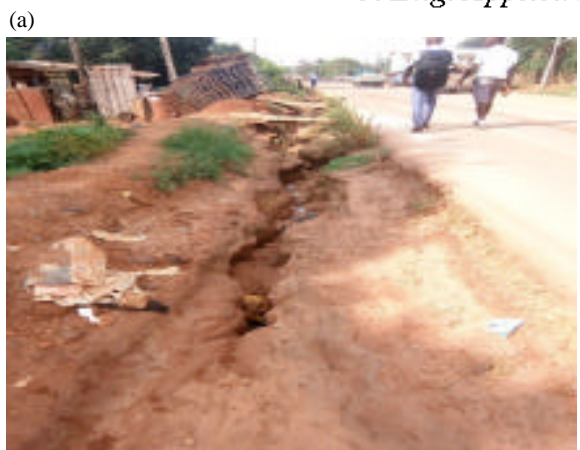

(b)

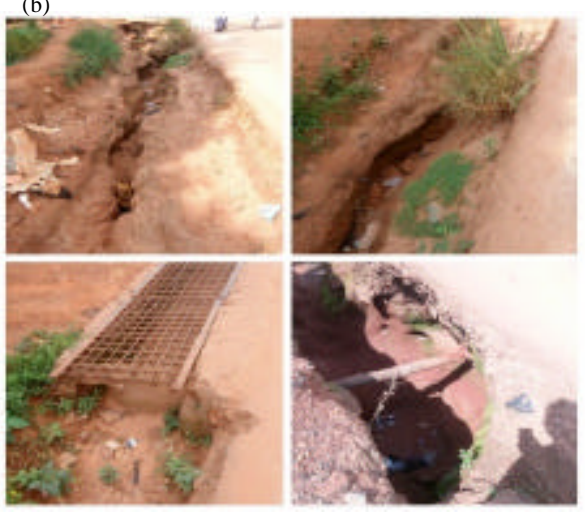

Fig. 21: a, b) Roads with temporary waste site, very good waste managements and very poor drainage condition, e.g., Onuiyi- Road

(a)

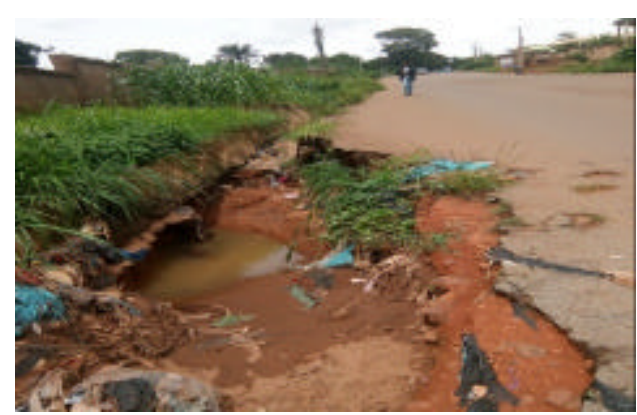

(b)

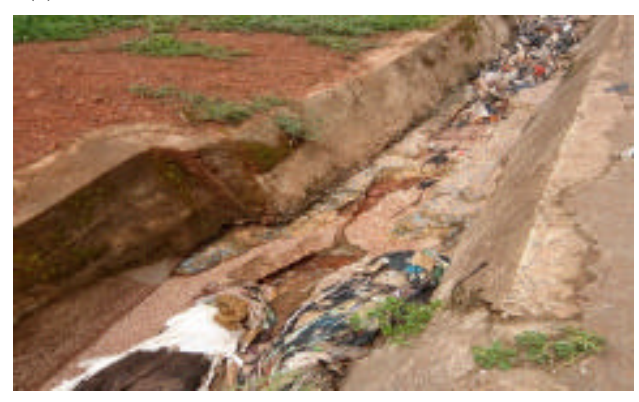

Fig. 22: a, b) Roads with temporary waste site, very poor waste managements and poor drainage condition, e.g., University market-Road

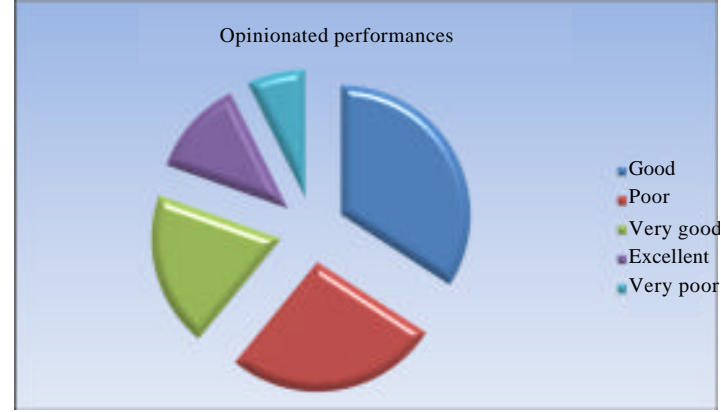

Fig. 23: A pie chart that shows the proportion of opinionated Road performance

(a)

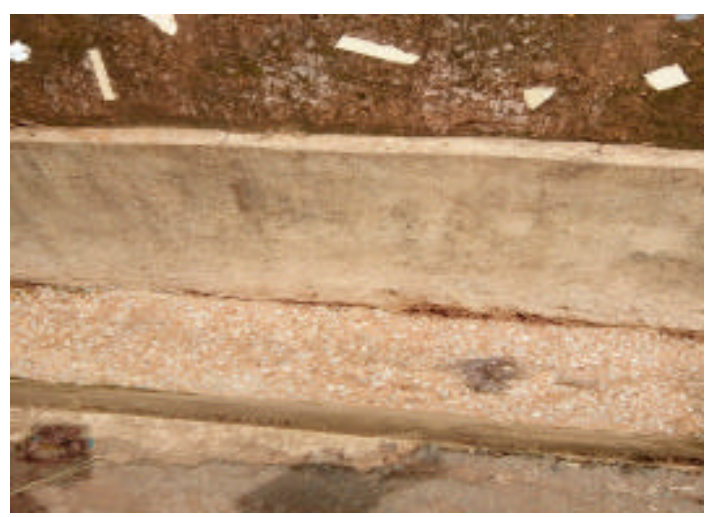

(b)

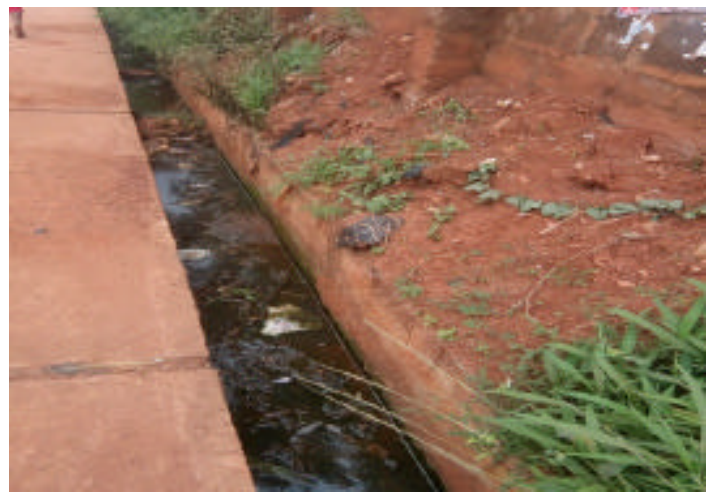

Fig. 24: a) Stone pitching method at University Market-Road and b) Un-stone pitched soil mass in Odenigbo Road

managements and poor drainage condition, e.g., University Market Road. Figure 22b shows Roads with temporary waste site, very poor waste managements and poor drainage condition, e.g., University Market-Road. From the questionnaire, more emphasis on good and sustainable Road drainage system for the Road sustainability is made by the correspondents at the rate of $68 \%$ (Fig. 23). 
(a)



(b)



Fig. 25: a) Cementing method with kerb in Odenigbo Road and b) Un-cemented soil mass at Enugu Road

Table 2: Summary of the condition of the drainage system and waste management psychology

\begin{tabular}{|c|c|c|c|}
\hline Road drainage system & Condition & Waste management & $\begin{array}{l}\text { Number of } \\
\text { temp orary } \\
\text { waste site }\end{array}$ \\
\hline Enugu-Road & Excellent & Good & None \\
\hline Orba-Road & Very good & Good & None \\
\hline Odenigwe-Road & Very good & Poor & None \\
\hline Odenigbo-Road & Good & Poor & 1 \\
\hline Aku-Road & Poor & Good & 1 \\
\hline University-Road & Poor & Poor & None \\
\hline Onuiyi-Road & Very poor & Very good & 4 \\
\hline University market-Road & Poor & Very poor & 1 \\
\hline
\end{tabular}

The result of Table 2 shows that the drainage in Enugu Road is in excellent condition with a good waste management even though it has no temporary waste site. Orba-Road drainage system follows almost the same trend. Odenigwe-Road has very good drainage system with a poor waste management, having no temporary waste site. Odenigbo-Road has good drainage system but a poor waste management system with only one temporary waste site. Aku-Road has a poor drainage system with only one temporary waste site but has a good waste management system. University-Road is the worst hitted, having poor drainage system and waste management system with no temporary waste site. Onuiyi-Road has a very good waste management system with four temporary waste sites but a very poor drainage system. Lastly University Market-Road has a poor drainage system and very poor waste management system with only one temporary waste site (Fig. 24 and 25).

\section{CONCLUSION}

This review was majorly concerned with the state of the Road drainage facilities in Nsukka town (urban) and to ascertain whether the existing drainage system was adequate. It is a general knowledge that good drainage is fundamental in the provision of a good Road network system. The greatest concern that prompted this study was the manner in which water disrupted traffic and further washed away parts of the roads in Nsukka town, e.g., University Market-Road, Onuiyi-Road, etc., during a heavy rainfall. It was established through this review that many of the drainage systems were not adequate. The responses from the engineers, Road users and residents equally showed that the problem lied in the drainage system. There was a general opinion that the drainage system should be looked into thoroughly. There is therefore, need for immediate remedies in order to achieve a good drainage system. Maintenance of the existing drainage facilities was also found to be poor. There is therefore, need to maintain the existing drainage facilities in order to mitigate to some extent the effects of water, especially, during the precipitation. Poor drainage of the Roads in Nsukka town has had a lot of far reaching consequences to the surrounding environment, residents and to the Road users. It has contributed to loss of property, loss of life and traffic diversions and discontinuation of journeys. Reasons for inadequate drainage systems included inadequate feasibility studies to ascertain the drainage requirements of the Road, corruption which leads to poor workmanship by the contractors and government officials who are mandated to supervise construction and lack of adequate resources to carry out maintenance on the drainage systems.

\section{RECOMMENDATIONS}

Measures should be drawn in order to curb the effect on poor waste management on Nsukka Road drainage system and construction flaws following it. Hence, recommendation should be stated as it helps to depict how to go about the sustainability of these drainage systems. They include:

- Introducing permanent waste sites where needed

- Increasing the number of temporary waste site where they are inadequate

- Improving cycling of the wastes to curtail the effect of poor waste management on Roads

- Maintenance of those drainage systems with severe damages 
- Introduction of stone pitching or cementation of exposed soil mass sloping at an angle to the drainage system to avoid latitudinal siltation

\section{ACKNOWLEDGEMENT}

The researcher appreciate the effort of Nweze, Arinze Charles in helping to carry out this project.

\section{REFERENCES}

Amit, K.D., 2016. Drainage system in highways: Term paper in transportation engineering. Lovely Professional University, Phagwara, India.

Leviakangas, P., 2015. Evaluation of Roadex benefits and savings. RoadEx America Inc., Gardena, California, USA.
Mama, C.N., P.I. Obe, C.C. Nnaji, K.G. Odo and K.O. Alumona et al., 2018. An investigation into drainage failures: A case study of University of Nigeria, Nsukka. Asian J. Water Environ. Pollut., 15: 115-123.

Michael, T., V.T. Iorver and E.T. Iortyom, 2016. The effects of poor drainage system on Road pavement: A review. Int. J. Innov. Res. Multidisciplinary Field, 2: $216-223$.

Mukherjee, D., 2014. Highway surface drainage system and problems of water logging in Road section. Intl. J. Eng. Sci., 3: 2319-1805.

Mwangi, 2013. A study on the maintenance of drainage systems on public Roads and pavements, a case study of nairobi's industrial area. BA Thesis, University of Nairobi, Nairobi, Kenya. 